the April 29 Council meeting. The Computer Users Section is the eighteenth APSA section organized, and was established for Association members "with interest in the use of computers in teaching, research, and policy applications in political science and all related subfields and disciplines.'

Interim officers of the Computer Users Group include:

President: Helen Purkitt, U.S. Naval Academy.

1988 Program Coordinator: Stephen Frantzich, U.S. Naval Academy.

Council: David Garson, North Carolina State University; Charles Benjamin, Bethel College; Robert G. Brookshire, James Madison University; Orville G. Cope, The College of Idaho; Bahram Farzanegan, University of North Carolina; Kenneth Janda, Northwestern University; and David A. Smeltzer, Portland State University.

The section will sponsor two sessions at the 1988 annual meeting. The panel, "Using Microcomputers for Substantive Analysis in the Classroom," will be held Friday, September 2 at 8:45 a.m.; "Using Com. puters for Classroom and Professional Analysis" will be held Thursday, September I at 1:30 p.m. The section's business meeting will also be on Thursday at 12:30 p.m.

Four APSA short courses offered on Wednesday, August 31 will also deal with computer hardware and software applications. Stephen Frantzich and Helen Purkitt will offer a short course at the U.S. Naval Academy on "Bringing Microcomputers to the Classroom"; Stuart Nagel, University of Illinois, Urbana-Champaign, will offer a course on "Microcomputers as Applied to All Fields of Political Science": Martha Swann, Catawba College, will address the use of on-line research (Lexis and Westlaw) for political scientists; and Clyde Tucker, Bureau of Labor Statistical Techniques, will examine federal statistical agencies and public use data sets.

\section{APSA Awards Ceremony and Presidential Address Changed to Friday}

The APSA Awards Ceremony and the Presidential Address of Kenneth N. Waltz, University of California, Berkeley, will be held on Friday, September 2, at 8:30 p.m. in the Washington Hilton Hotel. The ceremony and presidential address were changed from their customary Thursday evening time slot to accommodate the overlapping IPSA World Congress schedule.

1988 program co-chairs, John Ferejohn and Stephen Krasner, Stanford University, will preside over the annual presentation of awards. The 1988 APSA presidential reception will immediately follow President Waltz's address.

\section{Gabriel Almond Will Lecture on the State of the Political Science Discipline at IPSA World Congress}

Gabriel Almond, Stanford University, and former APSA President will introduce participants in the IPSA XIVth World Congress to the state of the political science discipline in the United States. Almond's presentation, "Separate Tables: Schools and Sects in Political Science," will be held Sunday, August 28, at 4:00 p.m. in the Sheraton Washington Hotel.

Almond's address will also be featured in the Fall 1988 issue of PS. For further information regarding the IPSA World Congress refer to the International Political Science section in this issue of PS. 